17. Mulloboeva Z. Is Bulgaria Losing the War on Corruption? [Електронний ресурс]. - Режим доступу: http://www.gfintegrity.org/is-bulgaria-losing-the-war-on-corruption/

18. Panev B. Report on a seminar on Prospects for Curbing Corruption in Bulgaria // BTA. - 2017. - 7 Feb.

19. Rankin J. Cloud of corruption hangs over Bulgaria as it takes up EU presidency. The Guardian. - 2017. - 27 Dec.

20. Smilov D., Dorosiev R. Perceptions of Corruption in Bulgaria A Content Analysis of Documents from Politics, Judiciary, Police, Media, Civil Society and Economy. Discussion Paper Series, 7 [Електронний ресурс]. - Режим доступу: https://kops.uni-konstanz.de/bitstream/handle/ 123456789/11427/Perceptions_of_corruption_in_Bulgaria.pdf? sequence=1

21. Tchompalova Y. Corruption in Bulgaria [Електронний ресурс]. - Режим доступу: https://irsocietyjcu.com/2018/01/10/corruption-in-bulgaria/

22. Zalan E. Ten years on, Romania and Bulgaria still dogged by corruption [Електронний ресурс]. - Режим доступу: https://euobserver.com/justice/136673

DOI 10.31558/2617-0248.2018.3.12

УДК 324:327

\title{
СУЧАСНИЙ СТАН ГЛОБАЛЬНОГО РОЗВИТКУ КУЛЬТУРИ ПОЛІТИЧНИХ ВИБОРІВ: УКРАЇНСЬКИЙ КОНТЕКСТ
}

\section{Панасенко Г. С., к. політ. н., доцент кафедри туристичного бізнесу та країнознавства Харківського національного університету імені В. Н. Каразіна}

\begin{abstract}
Говорячи про політичні вибори зазвичай мають надію на загальнодержавне або суспільне благо, проте через різноманіття самосвідомості та політичної свідомості, а також культуру політичних виборів кожен вбачає своє на шляху добробуту та безпеки. В сучасний глобальний період розвитку політична культура в Україні піддається деяким трансформаціям під впливом кризових явищ. У даній роботі розглядається специфіка культури політичних виборів саме в українському контексті. Сучасний процес глобального розвитку створює необхідність у розгляді формату політично активної людини у суспільстві особливо під час політичних виборів. Актуальною складовою та важливим аспектом розгляду культури політичних виборів $€$ національна політична мова, яка, характеризуючи окремі складові політичної культури, виступає засобом вираження політичних цінностей та мислення. Здійснюється спроба описати можливі варіанти розвитку культури політичних виборів у період найближчої виборчої кампанії. Автор надає комплексну характеристику сучасному стану глобального розвитку культури політичних виборів як соціального явища в Україні. Використовуються загальнонаукові методи: аналізу, синтезу, гіпотетичний метод. Наголошено, що реформи в Україні характеризуються надмірною повільністю через побутові традиції українського народу, які проектуються й у сферу політики. Автор доходить висновку, що, на жаль, ми ще застрягли в елітарній політичній культурі з владною структурою суспільства як базовою політичною цінністю і людиною як засобом для досягнення мети. Рівень політичної активності ще досі низький. Перспективними напрямами подальших досліджень $€$ постійне всебічне вивчення ролі та місця культури політичних виборів в Україні, особливо після чергових президентських виборів 2019 року.
\end{abstract}

Ключові слова: політична культура, культура політичних виборів,самосвідомість, політична свідомість, політичні вибори, виборча кампанія, глобальний розвиток.

Panasenko H. S. The current state of the global development of the culture of political elections: the Ukrainian context

Speaking about political elections, they usually pin their hopes on a nationwide or public benefit, but through a variety of self-consciousness and political consciousness, as well as a culture of political elections, everyone sees his own way on the path of welfare and security. In the modern global period of development, the political culture in Ukraine is subjected to some transformations under the influence of crisis phenomena.This paper examines the specificity of the culture of political elections in the Ukrainian context. The modern process of global development makes it necessary to consider the format of a politically active person in society, especially during political elections. An urgent component and an important aspect of considering the culture of political elections is national political speech, which, characterizing the individual components of political culture, is a means of expressing political values and thinking.An attempt is being made to describe possible options for the development of a culture of political elections in the period of the next election campaign. The author provides a comprehensive description of the current state of the global development of a culture of political elections as a social phenomenon in Ukraine. General scientific methods are used: analysis, synthesis, hypothetical method. It is noted that reforms in Ukraine are characterized by excessive slowness through the everyday traditions of the Ukrainian people, which are also projected in the sphere of politics. The author comes to the conclusion that, unfortunately, we are still stuck in the elite political culture with the power structure of society as a basic political value and a person as a means to achieve the goal. The level of political activity is still low. Perspective directions for further research are a constant comprehensive study of the role and place of culture of political 
elections in Ukraine, especially after the next presidential elections of 2019.

Key words: political culture, culture of political elections, self-consciousness, political consciousness, political elections, election campaign, global development.

Протягом усього періоду розвитку людства відбувається процес формування політичної культури в цілому і процес культури політичних виборів зокрема. У наш час глобального розвитку культура політичних виборів формується в родині, серед друзів, на роботі, в закладах освіти, в державі, а безпосередньо вибори - це подія завжди значно масштабніша, ніж регулярна, передбачена законом зміна керуючої верхівки.

Актуальність роботи полягає втому, що наприкінці грудня поточного року офіційно розпочнеться чергова президентська виборча кампанія в Україні, яка продемонструє сучасний стан розвитку культури політичних виборів саме в нашій країні. Оскільки процес взаємодії людини, суспільства з державою в умовах глобального розвитку $є$ джерелом розвитку та становлення демократії, то зазначене питання є сьогодні вельми актуальним.

Предметом дослідження є сучасна культура політичних виборів в українському контексті.

Мета статті - здійснити аналіз особливостей сучасного стану глобального розвитку культури політичних виборів напередодні чергової президентської кампанії України.

Для досягнення мети були поставлені наступні завдання:

• виокремити складові сучасної політичної культури;

- надати комплексну характеристику сучасному стану глобального розвитку культури політичних виборів як соціального явища в Україні;

- описати можливі варіанти розвитку культури політичних виборів у період найближчої виборчої кампанії;

- наголосити на співробітництві як необхідній формі взаємодії громадян у суспільстві в контексті культури політичних виборів.

У сучасних умовах глобального розвитку культура в цілому не перестає бути об'єктом вивчення серед істориків, філософів, суспільствознавців, політологів та ін. Уперше термін «політична культура» яскраво представлений у роботах німецького історика та політичного філософа Йогана-Готфріда Гердера. Починаючи з ХIX ст., вивченню цього поняття присвятили свої праці (в тому чи іншому аспектах): Р. Аграноф, Г. Алмонд, Х. Ашер, Д. Батлер, М. Бердяєва, К. Фон Бойме, М. Вебер, С. Верба, В. Гер’є, К. Гірц, М. Грушевський, Е. Джеймс, Д. Дівайн, Л. Дітмер, Д. Елазар, В. Іванівський, Р. Інглехарт, Р. Карр, П. Лазерсфельд, С. Ліпсет, К. Мангейм, К. Маркс, Ч. Меріам, Д. Мервік, Р. Мерельман, Б. Ньюман, Л. Пай, Ф. Плессер, Д. Поль, У. Розенбаум, Р. Роуз, М. Скаммел, Р. Такер, А. Токвіль, Д. Урінг, Ю. Хабермас, С. Хантінгтон та ін. Аналіз окремих аспектів виборчих технологій представлений у працях С. Боулера, Д. Маглебі, П. Мачіні, Е. Міцкевича, Р. Негріне, Д. Німмо, К. Патерсона, Дж. Свансона, Д. Фарела та ін.

Деякі аспекти української культури взагалі та політичної культури зокрема знаходимо в працях М. Костомарова, О. Кульчицького, В. Липинського, Д. Чижевського, М. Шлемкевича, П. Юркевича. У сучасних працях ця проблематика характеризується фрагментарністю дослідження. Сьогодні активно досліджують проблему політичної культури та виборів наші співвітчизники О. Поліщук, І. Поліщук, Ю. Швед та інші.

Сучасний глобальний процес настільки розмив зміст поняття «політична культура» (одних тільки визначень iз сім десятків), що його ототожнюють 3 усіма існуючими політичними процесами. Політична культура характеризується особливостями нації, рівнем збігу ціннісних орієнтацій населення, політичної участі та відкритості-закритості, механізмами соціального регулювання, геополітичним критерієм, формою державного правління, типом поведінки в конфліктах, проявом у зовнішній політиці, культурою та іміджем політичного та державного лідера, ставленням до суспільного прогресу й системними властивостями.

Головною функцією культури політичних виборів $є$ реалізація соціальних інтересів, узгодження яких зумовлює відповідну політичну поведінку соціальних спільнот та індивідів. Саме політична культура забезпечує стале, злагоджене та динамічне функціонування політичної системи, закріплюючи в суспільній свідомості конкретні політичні цінності та норми поведінки.

На думку нашого сучасника та співвітчизника I. О. Поліщука: «Політична культура - це сукупність типових, відносно сталих знань, уявлень, настанов, переконань, цінностей, орієнтацій, зразків поведінки, символів, яка склалася внаслідок історичного досвіду попередніх генерацій національної (соціальної) спільноти, транслюється від покоління до покоління, але має істотний трансформаційний потенціал та виявляється в діяльності суб'єктів політичного процесу та у функціонуванні політичних інститутів» [5, с. 125].

Політична культура являє собою сукупність цінностей, установок, переконань, орієнтацій і виражають їх символів, які є загальноприйнятими і служать упорядкування політичного досвіду і регулювання політичної поведінки всіх членів суспільства [6, с. 101].

Український учений Г.Новічков дає наступне визначення: «Політична культура - це типова, інтегральна характеристика індивідуального чи колективного соціального суб'єкта та соціальних інститутів, суспільства в цілому, що фіксує рівень розвитку їх політичної свідомості, політичної діяльності та поведінки» [4, с. 309].

За нашим сучасником - російським вченим Р.Мухаєвим, політична культура: «Це сукупність цінностей, настанов, переконань, орієнтацій та символів, що їх виражають, які $є$ загально прийнятими та служать упорядкуванню політичного досвіду та регулюванню політичної поведінки всіх членів суспільства. Вона включає в себе не тільки політичні ідеали, цінності та настанови, але й чинні норми політичного життя» [3, с. 258].

Політична культура за будовою характеризується взаємодією кількох, саме політичних, складових: дії, знання, зразки, ідеологія, інститути, норми, поведінка, психологія, свідомість, традиції та засоби політичної діяльності. Проте кожна з них також структурована. Політична культура має ще декілька компонентів політичних 
культур: відчуття, відносин, мислення, теоретичні і практичні загальнозначущі знання, функціонування політичних структур політичної і електоральної діяльності. Для індивіда політична культура визначається політичними: настроями, оцінками, переживаннями, переконаннями, почуттями тощо. Норми політичного життя разом з ідеалами, установками й цінностями також належать до політичної культури. Культура політичної свідомості та самосвідомості $є$ невід'ємним компонентом культури політичних виборів. Особливістю масової свідомості $є$ їі залежність від певної політичної ситуації.

Типи поведінки, які виділяють у соціології:

1) ідентифікація (проста і складна) як найпоширеніший процес виживання в соціумі;

2) індивідуалізація як форма вияву зрілого і нонконформного "Я" - суб'єкта, його самостійності;

3) інвестиція як форма найкориснішого для суспільства і людини розв'язання соціальних конфліктів;

4) маргіналізація як спосіб протистояння тотальній ідентифікації;

5) девіація як результат деструктивного виходу із внутрішнього конфлікту, який супроводжується максимумом емоцій і агресивно-руйнівною дією. Перелічені способи поведінки трапляються в усіх сферах суспільного життя, особливо у політичній [1, с. 148].

Для кожної особистості політична культура містить у собі правдиве або неправдиве знання про політику, почуття єдності чи віддаленості з політичними об'єктами, а також думки, оцінки і судження про них. Оволодіти в повній мірі культурою політичних виборів може тільки той, хто має високий рівень політичної культури, беручи активну участь в політиці.

Сучасний стан глобального розвитку культури політичних виборів в Україні характеризується:

- відсутністю:

взаємної довіри між окремими групами громадян;

віри у безпосередню здатність впливати на законодавчому рівні на уряд, політичні рішення тощо; домінування політичної скерованості у житті громадян;

національної гордості за положення політичної системи як у країні, так і на міжнародній арені; тенденції до єдності щодо діяльності та перспектив політичної системи країни; згоди серед громадян щодо ключових політичних питань; здатності йти на компроміси;

належної уваги до політичних подій в країні та світі;

а також:

- бажанням молодих людей брати участь в органах місцевого самоврядування та державній політиці;

- високим рівнем «політичної активності» особи під час обговорення та «вирішення» політичних проблем за святковим столом, у черзі тощо;володінням інформацією з одного-двох джерел;

- невмінням чітко висловити власні думки, особливо державною мовою;

- обранням агресивних методів впливу через високий рівень конфліктності та політичного невдоволення;

- суб'єктивною недалекоглядною оцінкою діяльності влади.

Актуальною складовою та важливим аспектом розгляду культури політичних виборів $є$ національна політична мова, яка, характеризуючи окремі складові політичної культури, виступає засобом вираження політичних цінностей та мислення.

Політична свідомість сучасного українця, - який звик пристосовуватися до різноманітних умов, терпіти, покладатися на Бога, радше сприймає політика зі звичним стилем аби було безконфліктно та комфортно, - завжди обирає менше $з$ двох зол. Реформи в Україні характеризуються надмірною повільністю через побутові традиції українського народу, які проектуються й у сферу політики.

У сучасний глобальний період розвитку політична культура в Україні піддається деяким трансформаціям під впливом кризових явищ. Українці діяльність представників органи влади спочатку оцінюють за етнопсихологічними та моральними якостями, а не за професійною результативністю. Отже, саме таке сприйняття породжує так зване політичне шахрайство та створення і розповсюдження різноманітних міфів.

Як зазначає Г. Куц, «у цілому, для українського менталітету характерні індивідуалізм, волелюбність, відторгнення авторитарного начала. Ці цінності певним чином корелюють з цінностями лібералізму. 3 іншої сторони, спостерігається також певна кореляція з принципами консерватизму» [2, с. 89].

Глобальна українська політична культура характеризується апатією, деформацією рис індивідуалізму (внаслідок довготривалого панування комуністичного режиму, який створив слабкі культурні риси) та споглядальною позицією за рахунок чого провідні позиції на міжнародній арені посідають більш активні конкуренти 3 високорозвинутими націями світу, а ми й досі не можемо сформувати відповідну ментальність й політичну культуру, оскільки продовжуються намагання розчленування України територіально, фрагментальна відсутність політичної діяльності, історична приналежність їі до країн з різними культурними та політичними системами 3 відчуженням населення на психологічному, побутовому та політичному рівнях, уривчаста денаціоналізація інтелігенції і под.

Українські політики постійно демонструють відсутність стійкої моральної позиції, нетерпимість до своїх політичних опонентів; не навчилися цивілізованими засобами розв'язувати конфлікти, тому маємо високу напругу в цій сфері життєдіяльності. Сьогодні продовжують своє існування настанова про збагачення будь-якою ціною, підлабузництво і продажність влади, заступництво, протекціонізм, елітарна солідарність, пліткарство, «посипання» брудом тощо.

Точкою відліку деяких позитивних змін у незалежній Україні стосовно політичної культури можна вважати "Помаранчеву" революцію, внаслідок якої стало відчуватися прагнення українців до свободи та соціальної 
справедливості. Проте тип політичної культури, який би мав відповідати сучасним настановам, у нашого населення досі не сформований.

В умовах сучасного глобального розвитку політико-культурному фактору у виборчому процесі належить одна з вирішальних ролей. Воля до справедливості та свободи є ключовими в цьому аспекті. Сьогодення вимагає від політичних сил здатності швидко діяти, перед цим 3 такою ж швидкістю все осмисливши, ідеологічного реформування, якісної підготовки управлінської еліти, уміння використовувати засоби масової інформації ідеологічну основу реформ. Під час якоїсь чергової виборчої кампанії ми бачимо позитивний образ політика 3 найкращими людськими якостями, який намагається задовольнити максимальну кількість прихильників різноманітних політичних ідеологій, і готовий брати на себе відповідальність за чи не найскладніший елемент політичного життя - прийняття політичних рішень.

Як відомо, сучасне суспільство в межах політичної системи функціонує за допомогою таких регулятивних механізмів як ринок і держава. Тому має місце неабияка конкуренція. За даними «Української правди» на попередніх виборах за часів незалежності України була така кількість кандидатів: 1991 рік - 6; 1994 рік - 7; 1999 рік - 13; 2004 рік - 26; 2010 рік - 18; 2014 рік - 21.

Близько півроку фактично триває будь-яка президентська кампанія (ії активна фаза). Чергові вибори Президента України мають відбутися 31 березня 2019 року. Як відомо, Президентом України може 35-річний громадянин України, який протягом десяти останніх років проживає в Україні та володіє українською мовою, має два мільйони п'ятсот тисяч гривень задля грошової застави. Йти можна від партії (одна партія - один кандидат) чи само висуванцем.

Ми всі чекаємо на 21 грудня 2018 року - день, коли своїм голосуванням Верховна Рада затвердить день виборів. Час офіційного висунення ще не настав, але вже про свою участь у виборчих перегонах заявили близько тридцяти чотирьох осіб, серед яких: Г. Балашов, Р. Безсмертний, О. Богомолець, І. Богословька, Ю. Бойко, I. Бубенчик, О. Вілкул, Д. Гнап, А. Гриценко, Ю. Дерев'янко, М. Добкін, Д. Добродомов, С. Каплін, І. Кива, Р. Кошулинський, В. Купрій, О. Ляшко, В. Наливайченко, Р. Насіров, О. Онищенко, П. Порошенко, Н. Савченко, А. Садовий, С. Тарута, М. Терещенко, Ю. Тимошенко, М Томенко, В. Чумак, І Шевченко, О Шевченко та інші.

Цифра висуванців є поки що рекордною для незалежної України, оскільки існують ще й «вірогідні» кандидати: С. Вакарчук, В. Зеленський, М Катеринчук, С. Мураєв, В. Новинський, О. Солонтай, А. Яценюк. Донбас.

Ймовірно, в більшості програм будуть церковні, мовні, економічні питання, а також анексований Крим і

Найстрашніше, що фактично кожний четвертий українець на планує брати участь в обранні президента (чи то $з$ власних міркувань, чи то з наявності низької політичної культури, чи то через відсутність «сильного» кандидата), то цифра виборців вразить своїм мінімалізмом.

Таким чином, сьогодні можемо констатувати беззаперечну актуальність питання культури політичних виборів, яка напередодні чергових президентських виборів дає можливість об'єктивно оцінити політичну дійсність та визначити перспективи розвитку нашого суспільства, яке всіма шляхами намагається крокувати до типової демократії.

Отже, сучасний стан глобального розвитку культури політичних виборів в Україні як соціального явища характеризується:

- великим періодом історичного розвитку; системах;

• відсутністю адекватного культурного контексту й відповідних характеристик суб'єктів, що діють у цих

• відсутністю більш-менш єдиного визначення ширшого поняття - «політична культура»;

- існуванням культури політичних виборів крізь призму двох площин: політичної та культурної;

- перспективою подальших досліджень за даною проблематикою;

- тим, що нова політична реальності в Україні почала загартовуватися ще в далекому 2004 році.

Перспективними напрямами подальших досліджень є постійне всебічне вивчення ролі та місця культури політичних виборів в Україні, особливо після чергових президентських виборів 2019 року.

Стосовно президентських виборів 2019 р. необхідно відзначити, що ще до початку виборчої кампанії ми вже відчуваємо застосування різноманітних технологій, які підтверджують відсутність необхідних компонентів культури політичних виборів в умовах сучасного глобального розвитку. Циклічно продовжує відбуватися спаплюжений впливу на громадську думку - те, що ми споглядаємо напередодні кожних виборів: сумнівні дані соціологічних опитувань подаються хіба що не кожного дня, які потім доволі вдало використовуються задля дискримінації окремих кандидатів через маніпуляцію такими даними, розповсюдження чуток і компромату відносно певних кандидатів (цього разу, наприклад, знов маємо спотворення зовнішності одного 3 кандидатів на численних біг-бордах у столиці), змагання «обіцянок», псевдопідкуп та багато іншого. Відповідно до статті 58 закону "Про вибори Президента України" можна агітувати проти інших учасників виборів, тому кандидати іiі «дослухаються». Оскільки ми живемо в епоху глобальних інформації та комунікації більш результативними, мабуть, стануть інформативні PR-технології та роль ЗMI, хоча не без традиційного домішку «брудних» технологій 3 маніпулятивною складовою. За серйозні порушення фактично нереально зняти кандидата в президенти з реєстрації, тому процвітає механізм політичної розправи. Адміністративний ресурс також може спрацювати не на користь чесних виборів, ризик зовнішнього втручання. Сьогоднішній політичний ринок характеризується конкурентністю $\mathrm{i}$ відносною цивілізованістю.

Березневі вибори 2019 року вже характеризуються відсутністю двох домінуючих кандидатів на противагу того, як було раніше. Отже, вже маємо високу конкуренцію за вихід у другий тур. Варто також відмітити зростання 
ролі політичної реклами, яка стала більш професійною в порівнянні з першим десятиліттям ХХІ століття. Отже, офіційно вибори не почалися, але кандидати давно почали агітацію.

Громадянська культура є різновидом демократичної політичної культури. Україна прагне громадянської політичної культури, оскільки наша сучасна політична система має демократичний характер, а тому потреби та інтереси людини, яка відчуває відповідальності за все, що відбувається, виходять на перший план. Саме тому достатньо високою має бути політична активність учасників політичного процесу. Проте, на жаль, ми ще застрягли в елітарній політичній культурі з владною структурою суспільства як базовою політичною цінністю і людиною як засобом для досягнення мети. Рівень політичної активності ще досі низький.

Узагальнюючи розгляд специфіки розвитку культури політичних виборів в українському контексті можна зробити такі висновки: застосування «брудних» виборчих технологій нікуди не дівається в усіх виборчих кампаніях, оскільки кожен кандидат зі своєю командою так чи інакше допускають можливість порушення правил передвиборчої боротьби, встановлених на законодавчому рівні; продовжує своє існування недосконале законодавство; відсутня належна громадянська увага та контролю за перебігом виборчого процесу; відсутність «сильного» кандидата та зневіра українського населення.

Отже, стан культури політичних виборів в умовах глобального розвитку багато в чому пояснює волевиявлення виборців. Вагомими тут залишаються активна політична свідомість громадян та національна самосвідомість кожної особистості задля подальшого вдалого розвитку нашої демократичної правової держави.

\section{Бібліографічний список:}

1. Гелей С.Д. Політологія [текст] : навч. посіб. : 8-ме вид. перероб. та доп. / С. Д. Гелей, С. М. Рутар - К. : «Центр учбової літератури», 2012. - 348 с.

2. Куц Г. М. Перипетії формування політичного режиму в пострадянській Україні: досвід Майданів / Г. М. Куц // Сучасне суспільство: політичні науки : зб. наук. пр. / Харк. нац. пед. ун-т ім. Г. С. Сковороди. - Х. : ФОП Петров В. В., 2014. - Вип. 1 (5). - С. 82-94

3. Мухаев Р.Т. Политология. Издание второе. - М.: «Издательство ПРИОР», 2000. - С. 258

4. Політологія / За ред. О.В.Бабкіної, В.П.Горбатенка. - К.: Видавничий центр „Академія”, 2001. - С. 309

4. Поліщук І. О. Генеза та сучасність концепції «політичної культури» // Грані. - 2005. - № 4. - С. 125-128

5. Тердер Т. І. Ідеї дол. Філософії історії людства. - М.: Наука, 1977. - С. 101 